\title{
Different Residues Affect Wheat Nutritional Composition
}

\author{
Juan Hirzel ${ }^{1}$ (1) Pablo Undurraga ${ }^{1} \cdot$ Lorenzo León $^{1} \cdot$ Marcelo Panichini $^{1} \cdot$ Jorge Carrasco $^{2} \cdot$ Jorge González $^{1}$. \\ Iván Matus ${ }^{1}$
}

Received: 22 May 2019 / Accepted: 11 September 2019 /Published online: 1 November 2019

(C) The Author(s) 2019

\begin{abstract}
Conservation agriculture using crop rotation benefits the environment, soil fertility, and crop production. A biannual rotation experiment during a period of 2 years was conducted in volcanic soil in south-central Chile in a production system under conservation agriculture. The experiment considered two previous crops, canola (Brassica napus L.) and bean (Phaseolus vulgaris L.), and four levels of residue incorporation $(0 \%, 50 \%, 100 \%$, and $200 \%$ of generated residue). Grain yield $\left(0.41 \mathrm{Mg} \mathrm{ha}^{-1}\right)$, grain sedimentation value $(5.5 \%)$, grain $\mathrm{K}(0.031 \%)$ and $\mathrm{Ca}(0.006 \%)$ concentrations, and residue $\mathrm{K}$ concentration $(0.159 \%)$ were higher when the previous crop was bean. The Ca concentration $(0.037 \%)$ in wheat residue increased after the canola crop. The different applied residue levels of the previous crop had no effect on any of the evaluated parameters in wheat. There was a very consistent negative correlation between the grain $\mathrm{S}$ concentration and the residue $\mathrm{P}(-0.55), \mathrm{K}(-0.55)$, $\mathrm{Mg}(-0.61)$, and $\mathrm{S}(-0.63)$ concentrations in wheat when it was cultivated after bean. A larger number of study cycles are required to obtain more consistent results about the effect of the different residue levels on these two biannual rotations.
\end{abstract}

Keywords Crop rotation $\cdot$ Residue management $\cdot$ Triticum aestivum $\cdot$ Nutrient concentrations

\section{Introduction}

Conservation agriculture and crop rotation benefit both the environment and soil fertility (Sommer et al. 2007); and it has different effects on crop production and nitrogen (N) use efficiency (Limon-Ortega et al., 2004; Kazemeini et al. 2014; Pandiaraj et al. 2015; Basir et al. 2016). Conservation agriculture can increase soil organic matter (SOM), biological activity, macroporosity, stable aggregates, water infiltration, and amount of soil water available to plant, and reduce bulk density (Fabrizzi et al. 2005; Wright et al. 2005; Liu et al. 2014a; Basir et al. 2016; Stewart et al. 2018; Urra et al. 2018). Formerly, Karlen et al. (1994) indicated that crop rotation allowed breaking soil pathogen cycles and reduced weed pressure. Hirzel et al. (2011) point out that crop rotation that

Juan Hirzel

jhirzel@inia.cl

1 Instituto de Investigaciones Agropecuarias, INIA Quilamapu, Av. Vicente Méndez 515, Chillan, Chile

2 Instituto de Investigaciones Agropecuarias, INIA Rayentué, Av. Salamanca s/n, km 105 ruta 5 sur, sector Los Choapinos, Rango, Chile included pastures increased soil chemical fertility. Pandiaraj et al. (2015) also demonstrated that wheat (Triticum aestivum L.) grain yield was higher after green gram (Vigna radiate [L.] Wilczek) compared with corn (Zea mays L.) used as a previous crop; this is associated with the fact that mineral $\mathrm{N}$ in the root-zone soil is often higher in a cereal-legume cropping system than in cereal monoculture. Kumar et al. (2018) indicated that different crop rotations generate changes in soil C mineralization, and the application of mineral fertilizers associated with crop residues had a positive effect on $\mathrm{C}$ and $\mathrm{N}$ mineralization and their kinetics. Besides, a permanent surface residue layer provides a barrier against rapid water runoff (Sommer et al. 2007). Residue incorporation reduces the quantity of chemical fertilizers used in the crop (Sfez et al. 2017), which could be associated with increased available nutrient concentrations and urease, alkaline phosphatase, and catalase activities in the top soil (Zhang Li et al. 2018). Chen et al. (2017) reported that the incorporation of both corn and wheat residues generated increased carbohydrate-derived components of SOM, with lower indices of aromaticity, alkyl $\mathrm{C} / \mathrm{O}$-alkyl C, and hydrophobicity/hydrophilicity than the control without added residues. These authors indicated that aromaticity was higher when applying corn residue than wheat residue. Several researchers are concerned about the influence of straw residue incorporation on crop growth and production 
(Kaur and Mahal 2017; Kazemeini et al. 2014; Wang et al. 2018).

In many situations, the benefits of continuous conservation agriculture practices in production systems can appear after several years (Lawrence et al. 1994; Sommer et al. 2007). For example, Sommer et al. (2007) indicated an approximate increase of $1 \mathrm{~g} \mathrm{~kg}^{-1}$ in organic $\mathrm{C}$ content in the first 20 -cm soil after 7 years under zero-tillage with retained residues. These authors also showed increased grain yield of $0.13 \mathrm{Mg} \mathrm{ha}^{-1}$ in corn cropped with conventional tillage when residues were retained in the soil with respect to their removal. Stewart et al. (2018) reported increased soil organic C of $3066 \mathrm{~kg} \mathrm{ha}^{-1}$ with the full incorporation of corn residues during 7 years of monocropping compared with their partial incorporation; furthermore, there was an increase in the arbuscular mycorrhizal fungal biomarker in the $0-7.5-\mathrm{cm}$ soil depth. A meta-analysis conducted by Liu et al. (2014b) indicated that crop straw incorporation increased in $13 \%$ and $42 \%$ total organic soil (TOS) and labile organic $\mathrm{C}$ fractions, respectively, as compared with management without residue incorporation. Govaerts et al. (2005) showed increased yield of $0.66 \mathrm{Mg} \mathrm{ha}^{-1}$ in corn and $0.12 \mathrm{Mg} \mathrm{ha}^{-1}$ in wheat in a cornwheat rotation with zero-tillage and retained field residues, as compared with the same tillage and residue management in corn or wheat monocropping. For conventional tillage practices of retaining residues in the field, these authors stated that the corn-wheat rotation increased corn and wheat grain yield by 0.83 and $0.10 \mathrm{Mg} \mathrm{ha}^{-1}$, respectively, with respect to monocropping in both crops. Pandiaraj et al. (2015) pointed out that crop residue incorporation increased wheat grain yield by 1.31 times and straw yield by 1.38 times, as compared with the control without residue incorporation. Basir et al. (2016) showed an increase of $12.0 \%$ and $3.5 \%$, in wheat grain yield with residue incorporation without $\mathrm{N}$ application compared with the practices of removing or burning the residues. In addition, Chen et al. (2018) indicated that straw incorporation increased rice and wheat grain yields by $11.6 \%$ and $11.1 \%$, respectively, as compared with the same crops managed without residue incorporation. In contrast to the benefits indicated by different authors for residue incorporation, Limon-Ortega et al. (2008) observed a decrease in grain yield of $0.2 \mathrm{Mg} \mathrm{ha}^{-1}$ in monocropping wheat when residue was incorporated instead of burning. As for biomass activity, Urra et al. (2018) showed increased arylsulphatase, alkaline phosphatase, $\beta$ glucosidase, and urease activities with corn stover incorporation with respect to its removal from the soil. In a soil managed as a permanent pasture, repeated addition of different plant residues (e.g., faba bean and wheat straw), $\mathrm{N}$ availability and microbial biomass $\mathrm{N}$ are influenced by residue rate and order (Truong and Marschner 2018).

Crop rotation and residue incorporation affect both crop productivity and soil fertility, but most of the time, these benefits are not seen in a short term, and it is necessary to carry on several experiments during several years to identify positive effects. Our hypothesis is that residue incorporation from a previous crop such as canola or bean does not negatively affect the wheat crop yield, but it does affect wheat plant nutritional composition, which contributes to demonstrating the short-time positive effect. Therefore, the objective of the present study was to evaluate the short-term effect of canola and bean as previous crops, and four residue levels of each crop, on grain yield, industrial grain quality, and nutritional composition of both the wheat grain and the residues.

\section{Material and Methods}

The experiment was conducted during the 2016-2017 and 2017-2018 crop seasons at the Santa Rosa Experimental Station $\left(36^{\circ} 31^{\prime} \mathrm{S} ; 71^{\circ} 54^{\prime} \mathrm{W}\right)$, Instituto de Investigaciones Agropecuarias, INIA Quilamapu, Chillán, Chile. The soil is of volcanic origin (Melanoxerands) and has low effective depth $(0.45 \mathrm{~m})$. The climate is temperate Mediterranean with a hot, dry summer and cold, wet winter with 605 and $563 \mathrm{~mm}$ precipitation for the 2016 and 2017 seasons, respectively, concentrated in winter and spring. The evaluations and analysis of results correspond to wheat in the 2017-2018 season.

\subsection{Experiment Management}

The crop rotations were canola (Brassica napus L.)-wheat (Triticum aestivum L.) and bean (Phaseolus vulgaris L.)wheat; agronomic practices normally used in Chile for these crops were standardized for the Chillán location. The canola cultivar was Eminem-von Baer, bean cultivar was TorcazaINIA, and wheat cultivar was Pandora-INIA.

The sowing dates for the first season of the experiment were 15 August and 27 October 2016 and the harvest dates were 5 April and 28 February 2017, for canola and bean, respectively. Wheat was sown on 5 July 2017 and harvested on 20 January 2018. Each experimental unit was a 40-m-long and 14-m-wide $\left(560 \mathrm{~m}^{2}\right)$ plot with $0.7-, 0.7-$, and $0.2-\mathrm{m}$ row spacing for canola, bean, and wheat, respectively.

Seed rates were 30,120 , and $220 \mathrm{~kg} \mathrm{ha}^{-1}$ for canola, bean, and wheat, respectively. Irrigation was applied in canola at the flowering and at the beginning of the grain-filling stages. Irrigation for bean was applied at $80 \%$ covered, $75 \%$ flowering, and at the beginning of the grain-filling stages. Irrigation in wheat was applied at the booting, heading, and milk to dough stages. Total weed control was carried out and disease control was not necessary. Lime was applied at the rate of $3000 \mathrm{~kg} \mathrm{ha}^{-1}$ prior to sowing canola and bean in April 2016. Nitrogen, $\mathrm{P}\left(\mathrm{P}_{2} \mathrm{O}_{5}\right)$, and $\mathrm{K}\left(\mathrm{K}_{2} \mathrm{O}\right)$ fertilization rates were 160,120 , and $80 \mathrm{~kg} \mathrm{ha}^{-1}$ in canola; 60,60 , and $60 \mathrm{~kg} \mathrm{ha}^{-1}$ in bean; and 240,120 , and $120 \mathrm{~kg} \mathrm{ha}^{-1}$ in wheat, in accordance with soil chemical properties (Table 1). In the three crops, $\mathrm{P}$ 
and $\mathrm{K}$ were applied $100 \%$ at sowing, while $\mathrm{N}$ was applied $50 \%$ at sowing and $50 \%$ at the $80 \%$ covering stage in canola, $100 \%$ at sowing in bean, and $15 \%, 45 \%$, and $40 \%$ at the sowing, tillering, and flag leaf stages in wheat. Fertilizer sources were urea, triple superphosphate, and potassium chloride. In addition, $\mathrm{Mg}, \mathrm{S}, \mathrm{Zn}$, and $\mathrm{B}$ were applied at rates of 30:33:8:4:2 $\mathrm{kg} \mathrm{ha}^{-1}$ before sowing in all crops, in accordance with the soil analysis (Table 1) with magnesium sulfate, zinc sulfate, and calcium borate fertilizers. Canola and bean grain yields were 3.2 and $3.8 \mathrm{Mg} \mathrm{ha}^{-1}$, respectively. At harvest, canola and bean residues were ground and incorporated at rates of $0 \%, 50 \%, 100 \%$, and $200 \%$ in the same experimental unit; so the main plot was divided into four split-plots of $20 \mathrm{~m}$ long and $7 \mathrm{~m}$ wide $\left(140 \mathrm{~m}^{2}\right)$ to evaluate the effect of the residue level on the parameters to evaluate in the wheat crop. The machines to grind and incorporate residues were a mulcher (Tornado 310, Maschio Gaspardo Iberica SPA, Barcelona, Spain) and a compact disc harrow (Rubin 9, Lemken $\mathrm{GmbH}$ and Co. KG, Alpen, Germany), respectively.

The experimental design was a split-split plot in which the main plot was the crop rotation (2) and the split plot was the residue level (4) with four replicates. Results were analyzed by ANOVA and Tukey's test $(p=0.05)$ using the SAS PROC MIXED Model procedure (SAS Institute, Cary, NC, USA). For the significant interactions, contrast analysis was used to separately compare treatment effects. In addition, a Pearson

Table 1 Soil chemical properties in $0-0.2 \mathrm{~m}$ depth before sowing canola and bean crops (2016-2017 season)

\begin{tabular}{|c|c|}
\hline Parameters & Value \\
\hline Clay, \% & 16.70 \\
\hline Silt, $\%$ & 44.60 \\
\hline Sand, $\%$ & 38.70 \\
\hline Bulk density, $\mathrm{g} \mathrm{cm}^{-3}$ & 1.00 \\
\hline $\mathrm{pH}_{\text {(soil:water 1:5) }}$ & 5.52 \\
\hline Organic matter, $\mathrm{g} \mathrm{kg}^{-1}$ & 109.20 \\
\hline $\mathrm{EC}, \mathrm{dS} \mathrm{m} \mathrm{m}^{-1}$ & 0.11 \\
\hline Available $\mathrm{N}, \mathrm{mg} \mathrm{kg}^{-1}$ & 54.10 \\
\hline Olsen $\mathrm{P}, \mathrm{mg} \mathrm{kg}^{-1}$ & 21.30 \\
\hline Exchangeable $\mathrm{K}, \mathrm{cmol}_{\mathrm{c}} \mathrm{kg}^{-1}$ & 0.54 \\
\hline Exchangeable $\mathrm{Ca}, \mathrm{cmol}_{\mathrm{c}} \mathrm{kg}^{-1}$ & 4.20 \\
\hline Exchangeable $\mathrm{Mg}, \mathrm{cmol}_{\mathrm{c}} \mathrm{kg}^{-1}$ & 0.36 \\
\hline Exchangeable $\mathrm{Na}, \mathrm{cmol}_{\mathrm{c}} \mathrm{kg}^{-1}$ & 0.08 \\
\hline Exchangeable $\mathrm{Al}, \mathrm{cmol}_{\mathrm{c}} \mathrm{kg}^{-1}$ & 0.12 \\
\hline Available $\mathrm{Fe}, \mathrm{mg} \mathrm{kg}^{-1}$ & 28.30 \\
\hline Available $\mathrm{Mn}, \mathrm{mg} \mathrm{kg}^{-1}$ & 1.70 \\
\hline Available $\mathrm{Zn}, \mathrm{mg} \mathrm{kg}^{-1}$ & 0.20 \\
\hline Available $\mathrm{Cu}, \mathrm{mg} \mathrm{kg}^{-1}$ & 1.20 \\
\hline Available $\mathrm{B}, \mathrm{mg} \mathrm{kg}^{-1}$ & 0.10 \\
\hline Available S, $\mathrm{mg} \mathrm{kg}^{-1}$ & 23.50 \\
\hline
\end{tabular}

$E C$ electrical conductivity correlation analysis was performed for all the analyzed parameters.

\subsection{Wheat Grain and Residue Yield, Grain Quality, and Plant Tissue Analysis}

Plots were harvested manually at grain maturity and grain and residue yield for each plot was expressed as $\mathrm{Mg} \mathrm{ha}^{-1}$. Plant samples from a $2.0 \mathrm{~m}^{2}$ plot area were collected and separated as grain and aerial residue. Grain and tissue samples were oven-dried at $70{ }^{\circ} \mathrm{C}$ for $72 \mathrm{~h}$.

Nitrogen, $\mathrm{P}, \mathrm{K}, \mathrm{Ca}, \mathrm{Mg}$, and $\mathrm{S}$ concentrations in grain and aerial residue were determined. Dried subsamples were ground with a mill, passed through a 2-mm sieve, and analyzed. After dry ashing at $500{ }^{\circ} \mathrm{C}$ and acid digestion $(2 \mathrm{M}$ $\mathrm{HCl}$ ), total $\mathrm{N}$ was determined by the macro-Kjeldahl procedure and total $\mathrm{K}, \mathrm{Ca}$, and $\mathrm{Mg}$ by atomic emission $(\mathrm{K})$ and atomic absorption ( $\mathrm{Ca}$ and $\mathrm{Mg}$ ) spectrophotometry. Phosphorus was measured in the same extracts by colorimetry in accordance with the molybdate ascorbic acid method. The turbidimetric determination of sulfate as barium chloride was performed.

\subsection{Grain Quality}

The wet gluten content and sedimentation value were determined in the grains. For sedimentation, the sodium dodecyl sulfate (SDS) test was conducted according to the procedure outlined by Peña et al. (1990). Gluten content was determined in 10 -g pure flour mixed with $5 \mathrm{~mL} 2 \%$ saline solution, homogenized, and then placed in a gluten washer (Promylograph type TIK, Austria) for $5 \mathrm{~min}$.

\section{Results}

Significance testing (Table 2) only showed the effects of the previous crop on yield $(p<0.01)$, sedimentation value $(p<$ $0.01)$, and $\mathrm{K}(p<0.01), \mathrm{Ca}(p<0.01)$, and $\mathrm{Mg}(p<0.05)$ concentrations in the grain. Wheat residue was only affected by the previous crop for the $\mathrm{K}$ and $\mathrm{Ca}(p<0.05)$ concentrations (Table 2). Meanwhile, the previous level of incorporated residue and its interaction on the previous crop had no significant effects $(p>0.05)$ (Table 2). Grain yield of the wheat crop fluctuated between 5.47 and $6.30 \mathrm{Mg} \mathrm{ha}^{-1}$ (Table 3 and Fig. 1), which was usual for the study area associated with the low effective soil depth (Hirzel et al. 2011). The highest grain yield was reached after the bean crop $(p<0.05)$ (Table 3 ). The highest sedimentation value and $\mathrm{K}$ and $\mathrm{Ca}$ concentrations in the wheat grain were also attained after the bean crop as well as a higher $\mathrm{K}$ concentration in wheat residue; however, $\mathrm{Ca}$ concentration in wheat residue was lower after bean (Table 3). The lowest Ca concentration in wheat 
Table 2 Statistical analysis of wheat grain yield, quality parameters, and nutritional concentrations in grain and residue

\begin{tabular}{lllll}
\hline Tissue & Parameter & Previous crop (C) & Residue level (R) & C $\times$ R Interaction \\
\hline \multirow{2}{*}{ Grain } & Yield & $* *$ & NS & NS \\
& Hectoliter weight & NS & NS & NS \\
& Wet gluten content & NS & NS & NS \\
& Sedimentation value & $* *$ & NS & NS \\
& N concentration & NS & NS & NS \\
& P concentration & NS & NS & NS \\
& K concentration & $* *$ & NS & NS \\
& Ca concentration & $* *$ & NS & NS \\
& Mg concentration & $*$ & NS & NS \\
S concentration & NS & NS & NS \\
& N concentration & NS & NS & NS \\
& P concentration & NS & NS & NS \\
& K concentration & $*$ & NS & NS \\
& Ca concentration & $*$ & NS & NS \\
Mg concentration & NS & NS & NS \\
\hline S concentration & NS & NS &
\end{tabular}

*, **Significant at the 0.05 and 0.01 probability levels, respectively; $N S$ nonsignificant residue and its higher concentration in wheat grain cultivated after bean compared with canola indicate higher $\mathrm{Ca}$ translocation to the grain associated with the previous crop, but it must be verified by the correlation analysis discussed below.

Table 3 Wheat grain yield, grain quality parameters, and nutritional concentrations in grain and residue after canola or bean crops

\begin{tabular}{llll}
\hline \multirow{2}{*}{ Tissue } & Parameter & \multicolumn{2}{l}{ Previous crop } \\
\cline { 3 - 4 } & & Canola & Bean \\
\hline \multirow{2}{*}{ Grain } & Yield, $\mathrm{Mg} \mathrm{ha}^{-1}$ & $5.74 \mathrm{~b}$ & $6.15 \mathrm{a}$ \\
& Hectoliter weight, $\mathrm{kg} \mathrm{hL}^{-1}$ & $78.14 \mathrm{a}$ & $78.64 \mathrm{a}$ \\
& Wet gluten content, \% & $41.16 \mathrm{a}$ & $40.50 \mathrm{a}$ \\
& Sedimentation value, $\mathrm{cm}^{3}$ & $46.54 \mathrm{~b}$ & $52.04 \mathrm{a}$ \\
& N concentration, \% & $2.305 \mathrm{a}$ & $2.293 \mathrm{a}$ \\
& P concentration, \% & $0.331 \mathrm{a}$ & $0.326 \mathrm{a}$ \\
& K concentration, \% & $0.509 \mathrm{~b}$ & $0.540 \mathrm{a}$ \\
& Ca concentration, \% & $0.060 \mathrm{~b}$ & $0.066 \mathrm{a}$ \\
& Mg concentration, \% & $0.126 \mathrm{a}$ & $0.116 \mathrm{a}$ \\
& S concentration; \% & $0.124 \mathrm{a}$ & $0.124 \mathrm{a}$ \\
Residue & N concentration, \% & $0.620 \mathrm{a}$ & $0.642 \mathrm{a}$ \\
& P concentration, \% & $0.038 \mathrm{a}$ & $0.039 \mathrm{a}$ \\
& K concentration, \% & $1.324 \mathrm{~b}$ & $1.483 \mathrm{a}$ \\
& Ca concentration, \% & $0.310 \mathrm{a}$ & $0.273 \mathrm{~b}$ \\
& Mg concentration, \% & $0.070 \mathrm{a}$ & $0.068 \mathrm{a}$ \\
& S concentration; \% & $0.097 \mathrm{a}$ & $0.093 \mathrm{a}$ \\
& & &
\end{tabular}

Different letters in the same row indicate significant differences according to Tukey's test $(p<0.05)$
The correlation analysis of wheat crop parameters after canola (Table 4$)$ indicated significant $(p<0.05)$ or highly significant correlations $(p<0.01)$. Grain yield was negatively correlated with hectoliter weight, grain $\mathrm{N}$ and $\mathrm{S}$ concentrations, and residue $\mathrm{K}$ concentration. On the other hand, grain yield was positively correlated with grain $\mathrm{K}$ concentration (Table 4). Hectoliter weight was negatively correlated with the sedimentation value and positively correlated with grain $\mathrm{S}$ concentration and residue K concentration (Table 4). Wet gluten content was positively correlated with the sedimentation value, but negatively correlated with both residue $\mathrm{K}$ and $\mathrm{S}$ concentrations (Table 4). The sedimentation value was also negatively correlated with residue $\mathrm{K}$ concentration (Table 4). As for nutrient concentrations, there was a positive correlation between grain $\mathrm{N}$ and $\mathrm{S}$ and residue $\mathrm{K}$ (Table 4), but a negative correlation with the grain $\mathrm{K}$ concentration. The grain $\mathrm{P}$ concentration was positively correlated with grain $\mathrm{Mg}$ concentration and negatively correlated with grain $\mathrm{S}$ concentration (Table 4). The grain $\mathrm{K}$ concentration was also positively correlated with grain $\mathrm{Ca}$ concentration and negatively correlated with grain S concentration (Table 4). Correlations for grain $\mathrm{Ca}, \mathrm{Mg}$, and $\mathrm{S}$ concentrations with other nutrients were already described, as were correlations between nutrient concentrations in the residue and other evaluated grain parameters (Table 4). However, significant correlations were observed between some nutrients found in the residue (Table 4). The residue $\mathrm{N}$ concentration was positively correlated with residue $\mathrm{P}, \mathrm{Ca}, \mathrm{Mg}$, and $\mathrm{S}$ concentrations (Table 4). Likewise, there was a positive correlation between the residue $\mathrm{P}$ concentration and residue $\mathrm{Mg}$ and $\mathrm{S}$ concentrations (Table 4). The residue $\mathrm{K}$ concentration was positively correlated with the residue $\mathrm{S}$ 
Fig. 1 Wheat grain yield after incorporating four residue levels of canola (A) and bean (B) crops. Different letters over the bars indicate significant differences according to Tukey's test $(p<$ $0.05)$. Lines over the bars correspond to the standard error
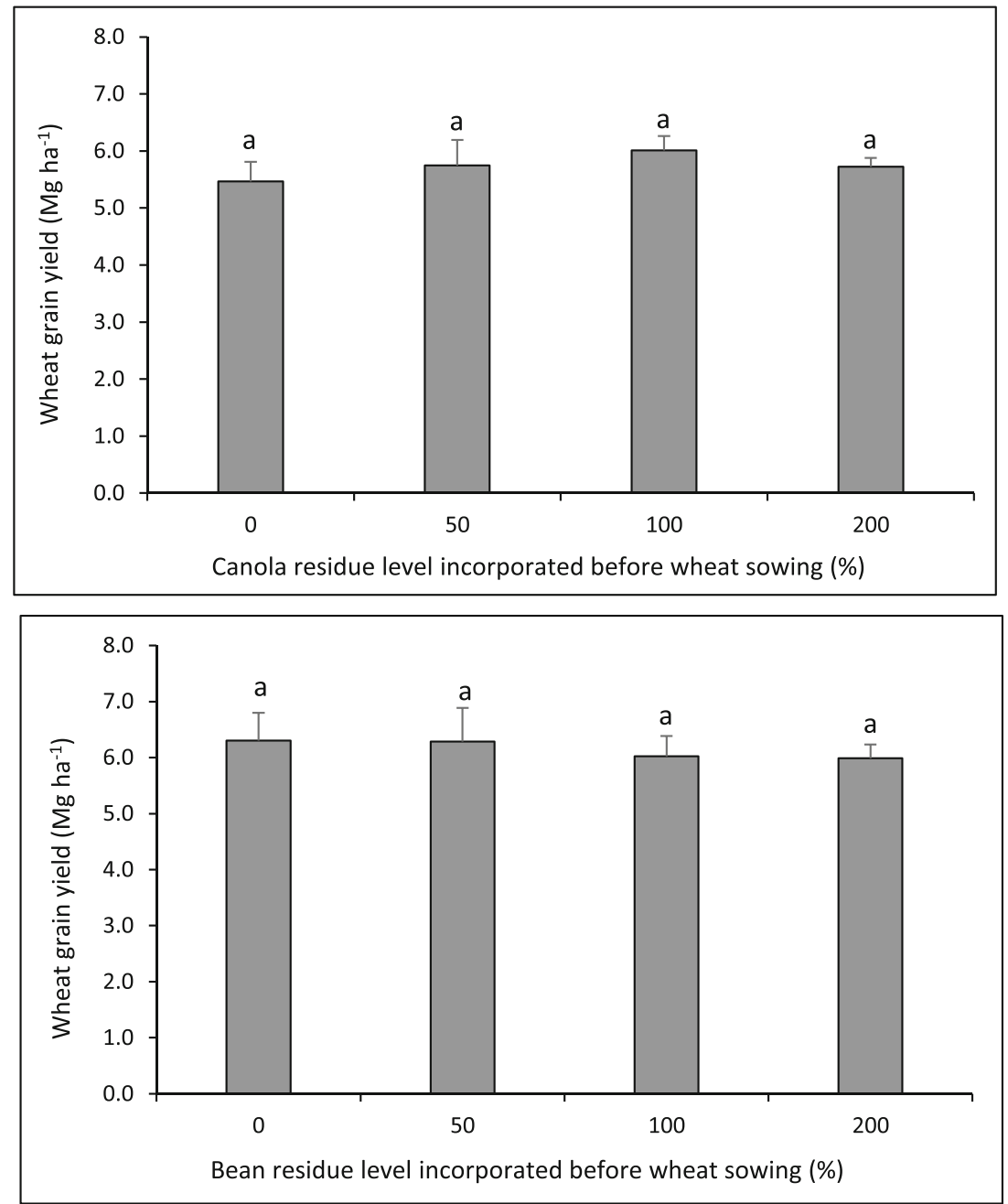

concentration. The residue $\mathrm{Ca}$ concentration was positively correlated with both residue $\mathrm{Mg}$ and $\mathrm{S}$ concentrations (Table 4). Finally, the residue Mg concentration was also positively correlated with residue S concentration (Table 4).

For the correlation analysis of evaluated wheat parameters after bean, some significant $(p<0.05)$ or highly significant $(p<$ 0.01 ) correlations were found (Table 5). Grain yield was positively correlated with grain $\mathrm{P}$ concentration and residue $\mathrm{N}, \mathrm{P}, \mathrm{K}$, $\mathrm{Mg}$, and $\mathrm{S}$ concentrations (Table 5). The wet gluten content was only positively correlated with the sedimentation value (Table 5). For the grain nutrient concentration, there was a positive correlation between $\mathrm{N}$ and the grain $\mathrm{S}$ concentration (Table 5) and between $\mathrm{P}$ and the residue $\mathrm{P}$ concentration (Table 5). The $\mathrm{K}$ concentration was positively correlated with grain Ca concentration (Table 5). On the other hand, S concentration was negatively correlated with residue $\mathrm{P}, \mathrm{K}, \mathrm{Mg}$, and $\mathrm{S}$ concentrations (Table 5). Correlations between residue nutrient concentrations and evaluated grain parameters (Table 5) were already described. For the residue nutrient concentrations (Table 5), a positive correlation was found between $\mathrm{N}$ and the $\mathrm{P}, \mathrm{K}, \mathrm{Mg}$, and $\mathrm{S}$ concentrations as well as positive correlations between $\mathrm{P}$ and the $\mathrm{K}, \mathrm{Mg}$, and $\mathrm{S}$ concentrations. The Ca concentration was positively correlated with the $\mathrm{Mg}$ and $\mathrm{S}$ concentrations (Table 5). Finally, there was a positive correlation between the Mg and S concentrations (Table 5).

\section{Discussion}

Effects of the previous crop on grain yield have been described by other authors (Govaerts et al. 2005; Hirzel et al. 2011; Pandiaraj et al. 2015). These effects can be associated with differences in residue nutritional contribution of previous crops or to the effect of residue composition on soil biomass, which can stimulate increased activity of beneficial soil microorganisms with positive effects on the productivity of the next crop (Kumar et al. 2018; Urra et al. 2018; Zhang Li et al. 2018).

Regarding the level of incorporated residues from different previous crops, the results of the present study differ from the positive effect on yield and nutritional properties or grain quality pointed out by several authors (Kaur and Mahal 
Table 4 Pearson correlation and significance level for wheat grain yield, grain quality parameters, and nutritional concentrations in grain and residue after canola crop

\begin{tabular}{|c|c|c|c|c|c|c|c|c|c|c|c|c|c|c|c|c|}
\hline & Yield & HW & WG & Sed & $\mathrm{N}_{\mathrm{G}}$ & $\mathrm{P}_{\mathrm{G}}$ & $\mathrm{K}_{\mathrm{G}}$ & $\mathrm{Ca}_{\mathrm{G}}$ & $\mathrm{Mg}_{\mathrm{G}}$ & $\mathrm{S}_{\mathrm{G}}$ & $\mathrm{N}_{\mathrm{R}}$ & $P_{R}$ & $\mathrm{~K}_{\mathrm{R}}$ & $\mathrm{Ca}_{\mathrm{R}}$ & $\mathrm{Mg}_{\mathrm{R}}$ & $\mathrm{S}_{\mathrm{R}}$ \\
\hline Yield & - & -0.59 & 0.34 & 0.34 & -0.89 & 0.38 & 0.62 & 0.31 & 0.17 & -0.82 & 0.01 & 0.22 & -0.62 & -0.06 & 0.28 & -0.08 \\
\hline HW & $*$ & - & -0.17 & -0.57 & 0.48 & -0.25 & -0.48 & -0.03 & -0.13 & 0.56 & 0.12 & 0.08 & 0.52 & 0.15 & -0.04 & 0.25 \\
\hline WG & $\mathrm{NS}$ & NS & - & 0.71 & -0.15 & 0.44 & 0.26 & 0.31 & 0.36 & -0.02 & -0.44 & -0.25 & -0.78 & -0.28 & -0.48 & -0.72 \\
\hline Sed & NS & $*$ & $* *$ & - & -0.17 & 0.11 & 0.36 & 0.18 & 0.01 & 0.01 & -0.19 & -0.23 & -0.63 & 0.01 & -0.24 & -0.44 \\
\hline $\mathrm{N}_{\mathrm{G}}$ & $* *$ & NS & NS & NS & - & -0.33 & -0.56 & -0.30 & -0.20 & 0.87 & -0.13 & -0.37 & 0.51 & -0.02 & -0.45 & -0.05 \\
\hline$P_{G}$ & $\mathrm{NS}$ & NS & NS & NS & NS & - & 0.28 & 0.31 & 0.84 & -0.52 & -0.29 & 0.12 & -0.42 & -0.39 & -0.12 & -0.45 \\
\hline $\mathrm{K}_{\mathrm{G}}$ & $* *$ & NS & NS & NS & $*$ & NS & - & 0.52 & 0.16 & -0.59 & 0.09 & 0.10 & -0.30 & -0.06 & 0.14 & 0.15 \\
\hline $\mathrm{Ca}_{\mathrm{G}}$ & $\mathrm{NS}$ & $\mathrm{NS}$ & NS & NS & $\mathrm{NS}$ & NS & $*$ & - & 0.20 & -0.31 & 0.16 & 0.21 & -0.35 & 0.04 & 0.12 & 0.01 \\
\hline $\mathrm{Mg}_{\mathrm{G}}$ & $\mathrm{NS}$ & $\mathrm{NS}$ & NS & NS & NS & $* *$ & NS & NS & - & -0.39 & -0.44 & -0.11 & -0.32 & -0.45 & -0.29 & -0.46 \\
\hline $\mathrm{S}_{\mathrm{G}}$ & $* *$ & $* *$ & NS & NS & $* *$ & $*$ & $*$ & NS & $\mathrm{NS}$ & - & 0.09 & -0.18 & 0.45 & 0.24 & -0.27 & 0.04 \\
\hline $\mathrm{N}_{\mathrm{R}}$ & NS & NS & NS & NS & NS & NS & NS & NS & NS & NS & - & 0.83 & 0.43 & 0.76 & 0.86 & 0.80 \\
\hline$P_{R}$ & $\mathrm{NS}$ & $\mathrm{NS}$ & NS & NS & $\mathrm{NS}$ & NS & NS & NS & $\mathrm{NS}$ & NS & $* *$ & - & 0.22 & 0.54 & 0.85 & 0.60 \\
\hline $\mathrm{K}_{\mathrm{R}}$ & $*$ & $*$ & $* *$ & $* *$ & $*$ & NS & NS & NS & $\mathrm{NS}$ & NS & NS & $\mathrm{NS}$ & - & 0.26 & 0.26 & 0.73 \\
\hline $\mathrm{Ca}_{\mathrm{R}}$ & $\mathrm{NS}$ & $\mathrm{NS}$ & NS & NS & $\mathrm{NS}$ & NS & NS & NS & NS & NS & $* *$ & $*$ & $\mathrm{NS}$ & - & 0.77 & 0.59 \\
\hline $\mathrm{Mg}_{\mathrm{R}}$ & $\mathrm{NS}$ & NS & NS & NS & NS & NS & NS & NS & NS & NS & $* *$ & $* *$ & NS & $* *$ & - & 0.74 \\
\hline $\mathrm{S}_{\mathrm{R}}$ & NS & NS & $* *$ & NS & $\mathrm{NS}$ & NS & NS & NS & NS & NS & $* *$ & $*$ & $* *$ & $*$ & $* *$ & - \\
\hline
\end{tabular}

Yield, wheat grain yield; $H W$, hectoliter weight; $W G$, wet gluten content; Sed, sedimentation value; $N_{G}, \mathrm{~N}$ concentration in the wheat grain; $P_{G}, \mathrm{P}$ concentration in the wheat grain; $K_{G}, \mathrm{~K}$ concentration in the wheat grain; $\mathrm{Ca}_{G}$, Ca concentration in the wheat grain; $\mathrm{Mg}_{G}, \mathrm{Mg}$ concentration in the wheat grain; $S_{G}$, S concentration in the wheat grain; $N_{R}, \mathrm{~N}$ concentration in the wheat residue; $P_{R}, \mathrm{P}$ concentration in the wheat residue; $K_{G}$, K concentration in the wheat residue; $C a_{R}$, Ca concentration in the wheat residue; $M g_{R}, \mathrm{Mg}$ concentration in the wheat residue; $S_{R}$, S concentration in the wheat residue

*,**Significant at the 0.05 and 0.01 probability levels, respectively; $N S$ nonsignificant

Table 5 Pearson correlation and significance level for wheat grain yield, grain quality parameters, and nutritional concentrations in grain and residue after the bean crop

\begin{tabular}{lllllllllllllllll}
\hline & Yield & $\mathrm{HW}$ & $\mathrm{WG}$ & $\mathrm{Sed}$ & $\mathrm{N}_{\mathrm{G}}$ & $\mathrm{P}_{\mathrm{G}}$ & $\mathrm{K}_{\mathrm{G}}$ & $\mathrm{Ca}_{\mathrm{G}}$ & $\mathrm{Mg}_{\mathrm{G}}$ & $\mathrm{S}_{\mathrm{G}}$ & $\mathrm{N}_{\mathrm{R}}$ & $\mathrm{P}_{\mathrm{R}}$ & $\mathrm{K}_{\mathrm{R}}$ & $\mathrm{Ca}_{\mathrm{R}}$ & $\mathrm{Mg}_{\mathrm{R}}$ & $\mathrm{S}_{\mathrm{R}}$ \\
\hline Yield & - & -0.10 & 0.01 & -0.38 & -0.38 & 0.69 & 0.34 & 0.09 & 0.49 & -0.38 & 0.66 & 0.87 & 0.70 & 0.01 & 0.56 & 0.73 \\
$\mathrm{HW}$ & $\mathrm{NS}$ & - & -0.29 & -0.29 & -0.20 & -0.27 & -0.29 & -0.25 & -0.37 & -0.01 & 0.02 & -0.12 & 0.04 & 0.14 & 0.09 & -0.14 \\
$\mathrm{WG}$ & $\mathrm{NS}$ & $\mathrm{NS}$ & - & 0.54 & -0.36 & 0.22 & -0.09 & -0.16 & 0.42 & -0.31 & -0.13 & -0.02 & 0.19 & 0.32 & 0.32 & 0.15 \\
$\mathrm{Sed}$ & $\mathrm{NS}$ & $\mathrm{NS}$ & $*$ & - & 0.24 & -0.15 & -0.08 & 0.06 & 0.47 & 0.22 & -0.11 & -0.32 & 0.02 & 0.20 & 0.06 & -0.24 \\
$\mathrm{~N}_{\mathrm{G}}$ & $\mathrm{NS}$ & $\mathrm{NS}$ & $\mathrm{NS}$ & $\mathrm{NS}$ & - & -0.22 & 0.17 & 0.24 & -0.08 & 0.68 & -0.22 & -0.35 & -0.34 & -0.05 & -0.48 & -0.48 \\
$\mathrm{P}_{\mathrm{G}}$ & $* *$ & $\mathrm{NS}$ & $\mathrm{NS}$ & $\mathrm{NS}$ & $\mathrm{NS}$ & - & 0.44 & 0.35 & 0.43 & -0.21 & 0.14 & 0.57 & 0.46 & -0.23 & 0.12 & 0.21 \\
$\mathrm{~K}_{\mathrm{G}}$ & $\mathrm{NS}$ & $\mathrm{NS}$ & $\mathrm{NS}$ & $\mathrm{NS}$ & $\mathrm{NS}$ & $\mathrm{NS}$ & - & 0.62 & 0.29 & 0.07 & 0.23 & 0.23 & -0.02 & -0.21 & -0.24 & 0.02 \\
$\mathrm{Ca}_{\mathrm{G}}$ & $\mathrm{NS}$ & $\mathrm{NS}$ & $\mathrm{NS}$ & $\mathrm{NS}$ & $\mathrm{NS}$ & $\mathrm{NS}$ & $*$ & - & 0.14 & 0.02 & -0.05 & 0.07 & -0.11 & -0.39 & -0.42 & -0.26 \\
$\mathrm{Mg}_{\mathrm{G}}$ & $\mathrm{NS}$ & $\mathrm{NS}$ & $\mathrm{NS}$ & $\mathrm{NS}$ & $\mathrm{NS}$ & $\mathrm{NS}$ & $\mathrm{NS}$ & $\mathrm{NS}$ & - & 0.13 & 0.25 & 0.29 & 0.31 & -0.03 & 0.28 & 0.28 \\
$\mathrm{~S}_{\mathrm{G}}$ & $\mathrm{NS}$ & $\mathrm{NS}$ & $\mathrm{NS}$ & $\mathrm{NS}$ & $* *$ & $\mathrm{NS}$ & $\mathrm{NS}$ & $\mathrm{NS}$ & $\mathrm{NS}$ & - & -0.42 & -0.55 & -0.55 & -0.33 & -0.61 & -0.63 \\
$\mathrm{~N}_{\mathrm{R}}$ & $* *$ & $\mathrm{NS}$ & $\mathrm{NS}$ & $\mathrm{NS}$ & $\mathrm{NS}$ & $\mathrm{NS}$ & $\mathrm{NS}$ & $\mathrm{NS}$ & $\mathrm{NS}$ & $\mathrm{NS}$ & - & 0.81 & 0.65 & 0.24 & 0.71 & 0.80 \\
$\mathrm{P}_{\mathrm{R}}$ & $* *$ & $\mathrm{NS}$ & $\mathrm{NS}$ & $\mathrm{NS}$ & $\mathrm{NS}$ & $*$ & $\mathrm{NS}$ & $\mathrm{NS}$ & $\mathrm{NS}$ & $*$ & $* *$ & - & 0.76 & 0.08 & 0.65 & 0.82 \\
$\mathrm{~K}_{\mathrm{R}}$ & $* *$ & $\mathrm{NS}$ & $\mathrm{NS}$ & $\mathrm{NS}$ & $\mathrm{NS}$ & $\mathrm{NS}$ & $\mathrm{NS}$ & $\mathrm{NS}$ & $\mathrm{NS}$ & $*$ & $* *$ & $* *$ & - & 0.26 & 0.79 & 0.65 \\
$\mathrm{Ca}_{\mathrm{R}}$ & $\mathrm{NS}$ & $\mathrm{NS}$ & $\mathrm{NS}$ & $\mathrm{NS}$ & $\mathrm{NS}$ & $\mathrm{NS}$ & $\mathrm{NS}$ & $\mathrm{NS}$ & $\mathrm{NS}$ & $\mathrm{NS}$ & $\mathrm{NS}$ & $\mathrm{NS}$ & $\mathrm{NS}$ & - & 0.60 & 0.46 \\
$\mathrm{Mg}_{\mathrm{R}}$ & $*$ & $\mathrm{NS}$ & $\mathrm{NS}$ & $\mathrm{NS}$ & $\mathrm{NS}$ & $\mathrm{NS}$ & $\mathrm{NS}$ & $\mathrm{NS}$ & $\mathrm{NS}$ & $*$ & $* *$ & $* *$ & $* *$ & $*$ & - & 0.83 \\
$\mathrm{~S}_{\mathrm{R}}$ & $* *$ & $\mathrm{NS}$ & $\mathrm{NS}$ & $\mathrm{NS}$ & $\mathrm{NS}$ & $\mathrm{NS}$ & $\mathrm{NS}$ & $\mathrm{NS}$ & $\mathrm{NS}$ & $* *$ & $* *$ & $* *$ & $* *$ & $\mathrm{NS}$ & $* *$ & - \\
\hline
\end{tabular}

Yield, wheat grain yield; $H W$, hectoliter weight; $W G$, wet gluten content; Sed, sedimentation value; $N_{G}, \mathrm{~N}$ concentration in the wheat grain; $P_{G}, \mathrm{P}$ concentration in the wheat grain; $K_{G}$, K concentration in the wheat grain; $\mathrm{Ca}_{G}$, Ca concentration in the wheat grain; $\mathrm{Mg}_{G}$, Mg concentration in the wheat grain; $S_{G}$, S concentration in the wheat grain; $N_{R}, \mathrm{~N}$ concentration in the wheat residue; $P_{R}, \mathrm{P}$ concentration in the wheat residue; $K_{G}$, K concentration in the wheat residue; $\mathrm{Ca}_{R}$, Ca concentration in the wheat residue; $M g_{R}, \mathrm{Mg}$ concentration in the wheat residue; $S_{R}$, $\mathrm{S}$ concentration in the wheat residue

*, **Significant at the 0.05 and 0.01 probability levels, respectively; NS nonsignificant 
2017; Kazemeini et al. 2014; Wang et al. 2018). However, our results correspond to only a biannual rotation cycle in which residue incorporation occurred only one season before the wheat crop. Given the high organic matter level of the experimental site (Table 1), the addition of organic $\mathrm{C}$ derived from the one-time residue incorporation during the crop rotation may have little effect on soil physical, chemical, and biological properties, and no effects on crop production or nutritional composition. Several authors have indicated that the effect of residue incorporation is observed a long time after carrying out this practice (Lawrence et al. 1994; Sommer et al. 2007).

In addition, negative effects have been reported by some authors; these effects are attributable to increased soil microorganisms caused by a high C:N ratio in straw and the promotion of fixed soil $\mathrm{N}$, which lead to insufficient $\mathrm{N}$ supply at the seedling stage and crop growth inhibition at the early growth stage (Thuy et al., 2006; Jin et al. 2013; Fu et al. 2013).

The positive effect of the bean crop on yield, sedimentation value, and concentrations of some grain and residue nutrients in the wheat crop can be associated with higher $\mathrm{N}$ contribution of a legume compared with a non-legume crop (Pandiaraj et al. 2015). It can also be the effect of residue incorporation with a low C:N ratio on soil biomass activity and SOM mineralization with contributions from nutrients and compounds that stimulate development and higher crop productivity (Kumar et al. 2018; Thuy et al., 2006; Urra et al. 2018; Zhang Li et al. 2018).

Regarding the correlations in the evaluated wheat grain and residue parameters after canola or bean, Koutroubas et al. (2016) have reported correlations between grain yield and $\mathrm{N}$ and $\mathrm{K}$ accumulation in wheat as well as a correlation between $\mathrm{N}$ and $\mathrm{P}$ translocation to the grain and its accumulation at anthesis. In the present study, a correlation was found between grain yield and grain $\mathrm{K}$ concentration for wheat after canola (Table 4). This partially coincides with results pointed out by Koutroubas et al. (2016) and contrast with these authors for correlations between grain yield and grain nutrient concentration after the bean crop (Table 5).

The negative correlation between grain yield and grain $\mathrm{N}$ concentration can be explained by the dilution effect on $\mathrm{N}$ concentration when yield increased; however, a negative correlation between grain yield and wet gluten content could not be confirmed (Table 4). The latter is a protein content indicator related to wheat grain glutenins and gliadins that are associated with grain $\mathrm{N}$ content. For the corn crop, Kovács and Vyn (2017) indicated a positive correlation between grain yield and $\mathrm{N}$, $\mathrm{P}$, and $\mathrm{S}$ concentrations in ear leaf samples at the midsilking stage, which is partially similar to the correlation obtained between grain yield and residue nutrient concentrations for wheat after bean (Table 5).

There was a consistently positive correlation between wheat grain $\mathrm{N}$ and $\mathrm{S}$ concentrations after both canola and bean (Tables 4 and 5), and this coincides with results reported by Kovács and Vyn (2017) for corn ear leaf samples at the mid- silking stage. Daur et al. (2011) also mention positive correlations between the grain yield of faba bean (Vicia faba L.) and $\mathrm{N}, \mathrm{P}, \mathrm{K}, \mathrm{Ca}$, and $\mathrm{Mg}$ uptake in the whole plant, which is similar to results for wheat grain yield and its correlations with residue $\mathrm{N}, \mathrm{P}, \mathrm{K}$, and $\mathrm{Mg}$ concentrations after bean (Table 5) and partially similar to results for wheat after canola (Table 4).

Positive correlations between nutrients have been described for corn leaves by Kovács and Vyn (2017) and can be associated with the effect of synergism (Fageria 2001), specifically the N-P, N-S, P-S, Ca-Mg, and Ca-S correlations and without pointing out negative correlations between nutrients. Similar results were found in the present study, that is, a positive correlation between wheat grain N-S and residue N-P, N-S, P-S, Ca$\mathrm{Mg}$, and $\mathrm{Ca}-\mathrm{S}$ for wheat after canola (Table 4). For the beanwheat rotation, our results were similar to those reported by Kovács and Vyn (2017) in the grain N-S and residue N-P, N$\mathrm{S}, \mathrm{P}-\mathrm{S}, \mathrm{Ca}-\mathrm{Mg}$, and Ca-S correlations (Table 5). Positive correlations are pointed out for faba bean between nutrient uptake for N-P, N-K, N-Ca, N-Mg, K-P, P-Ca, P-Mg, K-Ca, K-Mg, and $\mathrm{Ca}-\mathrm{Mg}$ (Daur et al. 2011). The abovementioned correlations are partially similar to those obtained in wheat grain nutrients and similar to those for wheat residue nutrients after canola (Table 4). On the other hand, wheat after bean correlations is very similar for residue nutrient concentrations (Table 5).

Positive correlations between the concentration of the same nutrient in the grain and residue were found only in the $\mathrm{P}$ concentration for wheat after bean (Table 5). Since this effect was not observed in wheat after canola, it could be inferred that there was a positive effect of the bean crop for $\mathrm{P}$ absorption and translocation in the wheat crop; however, P concentrations in both wheat grain and residue were similar to both previous crops (canola and bean) (Table 3 ).

Negative correlations between the concentration of the same nutrient in the grain and residue were found only in the $\mathrm{S}$ concentration for wheat after bean (Table 5), which suggests higher translocation of this nutrient from the residue to the grain when wheat precedes bean. The positive effect on $\mathrm{N}$ and $\mathrm{P}$ translocation for wheat has been reported by Koutroubas et al. (2016).

\section{Conclusions}

In the evaluated biannual rotations, wheat grain yield was higher when the previous crop was bean. The different applied residue levels of the previous crop had no effect on any of the evaluated wheat parameters for this short-term rotation.

Both positive and negative correlations were found between some grain and residue nutrient concentrations, which were described in the literature as the effect of synergism or antagonism. Positive correlations were much more consistent for nutrients present in wheat residue, independently of the previous crop. A very consistent negative correlation was 
obtained between the grain $\mathrm{S}$ concentration and residue $\mathrm{Ca}, \mathrm{K}$, $\mathrm{Mg}$, and $\mathrm{S}$ concentrations in wheat cultivated after bean.

Finally, a larger number of study cycles are required to obtain more consistent results about the effect of different residue levels on these two biannual rotations.

Funding Information This study was funded by grant number 500134-70, Instituto de Investigaciones Agropecuarias, Ministerio de Agricultura, Chile.

\section{Compliance with Ethical Standards}

Conflict of Interest The authors declare that they have no conflict of interest.

Open Access This article is distributed under the terms of the Creative Commons Attribution 4.0 International License (http:// creativecommons.org/licenses/by/4.0/), which permits unrestricted use, distribution, and reproduction in any medium, provided you give appropriate credit to the original author(s) and the source, provide a link to the Creative Commons license, and indicate if changes were made.

\section{References}

Basir A, Jan MT, Alam M, Shah AS, Afridi K, Adnan M, Ali K, Mian IA (2016) Impacts of tillage, stubble management, and nitrogen on wheat production and soil properties. Can J Soil Sci 97:133-140

Chen X, Mao A, Zhang Y, Zhang L, Chang J, Gao H, Thompson ML (2017) Carbon and nitrogen forms in soil organic matter influenced by incorporated wheat and corn residues. Soil Sci Plant Nutr 63: 377-387

Chen Z, Wang Q, Wang H, Bao L, Zhou J (2018) Crop yields and soil organic carbon fractions as influenced by straw incorporation in a rice-wheat cropping system in southeastern China. Nutr Cycl Agroecosyst 112:61-73

Daur I, Sepetoğlu H, Sindel B (2011) Dynamics of faba bean growth and nutrient uptake and their correlation with grain yield. J Plant Nutr 34:1360-1371

Fabrizzi KP, García FO, Costa JL, Picone LI (2005) Soil water dynamics, physical properties and corn wheat responses to minimum and notillage systems in the southern Pampas of Argentina. Soil Tillage Res 81:57-69

Fageria VD (2001) Nutrient interactions in crops plants. J Plant Nutr 24: $1269-1290$

Fu MY, Zhu LQ, Li Y, Bian XM (2013) Effects of straw concentration and deep embedding on rice growth and yield. Jiangsu Agric Sci 41:67-69

Govaerts B, Sayre KD, Deckers J (2005) Stable high yields with zero tillage and permanent bed planting? Field Crop Res 94:33-42

Hirzel J, Undurraga P, González J (2011) Chemical properties of volcanic soil as affected by seven years rotations. Chilean J Agr Res 71:304-312

Jin X, Cai LI, Li GH, Hou PF, Wang SH (2013) Effects of all wheat crop straw application on rice growth and redox substance in rice fields. Soils Fert Sci in China 5:80-85

Karlen DL, Varvel GE, Bullock DG, Cruse RM (1994) Crop rotations for the 21st century. Adv Agron 53:1-45

Kaur J, Mahal SS (2017) Affluence of paddy straw mulch on crop productivity and economics of bed and fiat sown wheat (Triticum aestivum) under different irrigation schedules. J Environ Biol 38: 243-250

Kazemeini SA, Bahrani MJ, Pirasteh-Anosheh H, Mehdi SM (2014) Maize growth and yield as affected by wheat residues and irrigation management in a no-tillage system. Arch Agron Soil Sci 60(11): $1543-1552$

Koutroubas S, Antoniadis V, Damalas C, Fotiadis S (2016) Effect of organic manure on wheat grain yield, nutrient accumulation, and translocation. Agron J 108:615-625

Kovács P, Vyn T (2017) Relationships between ear-leaf nutrient concentrations at silking and corn biomass and grain yields at maturity. Agron J 109:2898-2906

Kumar M, Kundu DK, Ghorai AK, Mitra S, Singh SR (2018) Carbon and nitrogen mineralization kinetics as influenced by diversified cropping systems and residue incorporation in Inceptisols of eastern Indo-Gangetic Plain. Soil Tillage Res 178:108-117

Lawrence PA, Radford BJ, Thomas GA, Sinclair DP, Key AJ (1994) Effects of tillage practices on wheat performance in a semi-arid environment. Soil Tillage Res 28:347-364

Limon-Ortega A, Govaerts B, Sayre KD (2008) Straw management, crop rotation, and nitrogen source effect on wheat grain yield and nitrogen use efficiency. Eur J Agron 29:21-28

Liu YC, Zeng XZ, Feng WQ, Qin YS, Wang CQ, Tu SH (2014a) Effects of long-term straw mulch and fertilization on crop yields and soil physical and chemical properties under rice-rapeseed rotation. $\mathbf{J}$ Plant Nutr Fertil 20:1450-1459

Liu C, Lu M, Cui J, Li B, Fang CM (2014b) Effects of straw carbon input on carbon dynamics in agricultural soils: a meta-analysis. Glob Chang Biol 20:1366-1381

Pandiaraj T, Selvaraj S, Ramu N (2015) Effects of crop residue management and nitrogen fertilizer on soil nitrogen and carbon content and productivity of wheat (Triticum aestivum L.) in two cropping systems. J Agric Sci Technol 17:249-260

Peña RJ, Amaya A, Rajaram S, Mujeeb-Kazi A (1990) Variation in quality characteristics associated with some spring $1 \mathrm{~B} / 1 \mathrm{R}$ translocations wheats. J Cereal Sci 12:105-112

Sfez S, De Meester S, Dewulf J (2017) Co-digestion of rice straw and cow dung to supply cooking fuel and fertilizers in rural India: impact on human health, resource flows and climate change. Sci Total Environ 609:1600-1615

Sommer R, Wall PC, Govaerts B (2007) Model-based assessment of maize cropping under conventional and conservation agriculture in Highland Mexico. Soil Tillage Res 94:83-100

Stewart C, Roosendaal D, Manter D, Delgado J, Del Grosso S (2018) Interactions of stover and nitrogen management on soil microbial community and labile carbon under irrigated no-till corn. Soil Sci Soc Am J 82:323-331

Thuy NH, Shan YH, Singh BJ, Wang KR, Cai ZC, Singhc Y (2008) Nitrogen supply in rice-based cropping systems as affected by crop residue management. Sci Soc Am J 72:514-523

Truong THH, Marschner P (2018) Amendment with high and low C/N residues- influence of rate, order and frequency. J Soil Sci Plant Nutr 18:705-720

Urra J, Mijangos I, Lanzén A, Lloveras J, Garbisu C (2018) Effects of corn stover management on soil quality. Eur J Soil Biol 88:57-64

Wang XJ, Jia ZK, Liang LY, Zhao YF, Yang BP, Ding RX (2018) Changes in soil characteristics and maize yield under straw returning system in dryland farming. Field Crop Res 218:11-17

Wright AL, Hons FM, Matocha JE (2005) Tillage impacts on microbial biomass and soil organic carbon and nitrogen dynamics of corn and cotton rotations. Appl Soil Ecol 29:85-92

Zhang Li WJ, Fu G, Zhao Y (2018) Rotary tillage in rotation with plowing tillage improves soil properties and crop yield in a wheatmaize cropping system. PLoS One 13(6):e0198193. https://doi.org/ 10.1371/journal.pone. 0198193

Publisher's Note Springer Nature remains neutral with regard to jurisdictional claims in published maps and institutional affiliations. 